Research Article

\title{
Yield and Growth Response of Maize (Zea mays L.) to Varietal and Nitrogen Application in the Guinea Savanna Agro-Ecology of Ghana
}

\author{
Alhassan Bawa \\ Department of Sustainable Agriculture, Tamale Technical University, Tamale, Ghana \\ Correspondence should be addressed to Alhassan Bawa; abawai1@yahoo.com
}

Received 21 June 2021; Revised 3 November 2021; Accepted 15 November 2021; Published 13 December 2021

Academic Editor: Yunchao Tang

Copyright (c) 2021 Alhassan Bawa. This is an open access article distributed under the Creative Commons Attribution License, which permits unrestricted use, distribution, and reproduction in any medium, provided the original work is properly cited.

\begin{abstract}
Background and Objective. Maize is one of the oldest cultivated crops. It is the third most important cereal after wheat and rice globally. Compared to all other cereals, maize has the highest average yield per unit area. The objective of the research was to evaluate maize varietal response to different nitrogen fertilizer rates. Materials and Methods. The treatment consisted of two factors, namely six varieties of maize and four levels of nitrogen application rates. These were arranged in $6 \times 4$ factorial combinations and laid out using randomized complete block design (RCBD) with three replications. The data collected were subjected to combined analysis for variation in factorial experiments in RCBD using Genstat statistical package edition 18. The means were separated using Duncan's multiple range test at a 5\% probability level. Results. The study revealed that varieties, such as IWD-C3-SYN-F2 and OBATAMPA, produced the highest grain yield and growth parameters (agronomic traits) relative to other varieties. The maximum grain yield and biomass production also occurred at the nitrogen application rates of 90 and $120 \mathrm{~kg} \mathrm{~N} / \mathrm{ha}$. Conclusion. Varieties, such as IWD-C3-SYN-F2 and OBATAMPA, and N rate of $90 \mathrm{~kg} \mathrm{~N} / \mathrm{ha}$ are, therefore, recommended to be used for maize production by the resource-poor farmers in the Guinea Savanna Agro-Ecology of Ghana.
\end{abstract}

\section{Introduction}

Maize or corn (Zea mays L.) is a plant belonging to the tribe Maydeae of the grass family Graminae (Poaceae). It is a native of Southern Mexico [1]. Maize is a versatile crop grown over a range of agroclimatic zones [2]. The genus Zea (Zela) was derived from an old Greek name for food grass. The genus Zea consists of four species of which Zea mays L. is economically important. The other Zea species, referred to as teosintes, are largely wild grasses native to Mexico and Central America [2]. The number of chromosomes in Zea mays is $2 n=20$. Maize is a tall, determinate, and monoecious plant. The plant has separate staminate and pistillate flowers on the same plant. It is an annual $\mathrm{C}_{4}$ plant varying in height from 1 to $4 \mathrm{~m}$ [3]. Maize is generally a protandrous plant, i.e., the maize flower matures earlier than the female.

According to [4], maize ranks third globally in the area and total production after wheat and rice. Maize remains an essential cereal crop and is a polyvalent seed. A large percentage of maize produced in Africa is utilized for household consumption even though it is progressively used for feeding animals [5]. In Northern Ghana, maize stovers are used as fuelwood [6], and for several decades, maize has been used as an industrial raw material from which products, such as cornflakes, oil, jam, alcohol, and paper are produced.

The current area planted to maize in Ghana stands at approximately 1 million ha. The per capita consumption of maize in Ghana is estimated at $44 \mathrm{~kg} /$ person/year, and the national demand is forecast to grow at approximately $1.83 \%$ per annum [7]. It is an important cereal produced in all five agroecological zones of Ghana. These include forest, Guinea savanna, coastal savanna, transitional zone, and Sudan savanna [8]. The Guinea and Sudan savannas, however, have the highest potential for increased maize production and productivity because of high solar radiation, low night temperatures, and low incidence of diseases [6]. Maize is one of the country's major food security crops. It also remains 
Ghana's most consumed cereal crop with surging production since 1965 [9]. Maize is largely the utmost prudent cereal crop in Ghana, and it is cultivated largely by rural and peri-urban farm families and resource-poor smallholder farmers [10]. It is extensively eaten nationwide and is Ghana's second most essential staple food after cassava [11]. The maize crop, however, has a minimum stress tolerance among the three main cereal crops [12].

Maize production in Ghana is bedeviled with problems of soil degradation, low soil nutrient levels (particularly nitrogen and phosphorus), inappropriate fertilizer application, leaching of soil minerals, and bush burning. It has been the major cause of the low yield of maize in the guinea savanna agroecology of Ghana [13]. The average maize grain yield is approximately 1.7 tons/ha as against an estimated achievable yield of approximately 6.0 tons/ha [14] as a result of low nitrogen and phosphorus levels in the soil, inappropriate fertilizer application, drought, and Striga infestation [15]. Nitrogen is an essential part of chlorophyll [16] and also forms a significant unit of many enzymes, nucleic acids, and proteins. Therefore, the deficiency or overapplication of nitrogen affects maize yields negatively [17]. An optimal nitrogen application enhances the protein content aside from the resultant significant increase in the yield of the maize crops [18]. Nitrogen deficiency stems from low crop development, which reduces the crop yield, leaf area, leaf number, and photosynthetic rate. To boost the productivity of the maize crop, various nitrogen fertilizer application regimes need to be critically examined to determine the optimum $\mathrm{N}$ application rate for increased maize grain production. The objective of the study was to examine the varietal response of maize to different nitrogen fertilizer application rates.

\section{Materials and Methods}

2.1. Experimental Area. The studies were conducted at Nyankpala in the Northern Region of Ghana during the 2016 and 2017 cropping seasons. The experimental site has tree and weed species, such as Neem tree (Azadirachta indica), Shea tree (Vitellaria paradoxa), Dawadawa tree (Parkia biglobosa), Teak (Tectona grandis), Broom weed (Sida acuta), Spear grass (Imperata cylindrica), Pigweed (Boehevia difusa), and Andropogon gayanus [19]. The soil in the area is of the Nyankpala series and is mainly made up of sand and loam. Rainfall, temperature, and relative humidity distribution in the area during the field studies were as shown in Tables 1-3. The rainfall, temperature, and relative humidity data were taken at the agrometeorological station of the CSIR-Savanna Agricultural Research Institute.

2.2. Soil Analysis. Before planting, the soil samples were arbitrarily collected from four different cores from $0 \mathrm{~cm}$ to $15 \mathrm{~cm}$ for the determination of soil physical and chemical properties using a soil auger. The results from soil analysis indicated that the soils at the experimental site were largely Sandy loam and classified as Ferric Acrisol, equivalent to
Typic Haplustult in the USDA soil classification system. The soil $\mathrm{pH}$ was 6.5 with very low nitrogen and organic matter content. The result of the initial soil analysis is presented in Table 4.

\subsection{Land Preparation, Planting, and Experimental Design.} The experiments were conducted at the experimental field of the CSIR-Savanna Agricultural Research Institute (SARI) at Nyankplala in the Northern Region of Ghana. In each of the experimental year, the land was prepared by ploughing, after which all debris was removed. Land demarcation was done using lining and pegs. The prepared land was leveled using a hoe before the seeds of the genotypes were planted. Six maize varieties obtained from the Savanna Agricultural Research Institute (SARI) of the Council for Scientific and Industrial Research (CSIR) were screened under four nitrogen fertilizer application rates for improved grain yield, yield components, and other growth/agronomic characteristics during the 2016 and 2017 cropping seasons under field experimental conditions. The treatment consisted of two factors, namely six varieties of maize and four levels of nitrogen application rates.

The six varieties used for the study were TZE-W-DTSTR-C4, IWD-C3-SYN-F2, GH120 DYF/D POP, OBATAMPA, DT-STR-W-C2, and COMP 1 SYN. The four nitrogen rates used for the study were $0 \mathrm{~kg} \mathrm{~N} / \mathrm{ha}, 60 \mathrm{~kg} \mathrm{~N} / \mathrm{ha}$, $90 \mathrm{~kg} \mathrm{~N} / \mathrm{ha}$, and $120 \mathrm{~kg} \mathrm{~N} / \mathrm{ha}$. These were arranged in $6 \times 4$ factorial combinations and laid out using randomized complete block design (RCBD) with three replications. The control plants $(0 \mathrm{~kg} / \mathrm{ha} \mathrm{N})$ did not receive nitrogen fertilizer. The furrows between the blocks/replications were $1.5 \mathrm{~m}$, while a $1 \mathrm{~m}$ space was left in between the plots. A plot size of $6 \mathrm{~m} \times 4 \mathrm{~m}$ was used with a planting distance of $75 \mathrm{~cm} \times 40 \mathrm{~cm}$. Planting was done in July 2016 and 2017 . Three seeds per hill were planted and later thinned out to two per hill after germination. The plant populations for all plots were 66,666 plants/ha.

2.4. Cultural Practices. Four nitrogen fertilizer regimes were applied $(0 \mathrm{~kg} \mathrm{~N} / \mathrm{ha}, 60 \mathrm{~kg} \mathrm{~N} / \mathrm{ha}, 90 \mathrm{~kg} \mathrm{~N} / \mathrm{ha}$, and $120 \mathrm{~kg} \mathrm{~N} /$ ha). The side placement method of fertilizer application was employed in a split application. Basal fertilizer (NPK 15-1515) was applied at 2 weeks after planting at the rate of 0 and $45 \mathrm{~kg} \mathrm{NPK} \mathrm{ha}^{-1}$. The plants were top-dressed with additional $\mathrm{N}$ using urea at the rate of $0,15,45$, and $75 \mathrm{~kg} \mathrm{Nha}^{-1}$ at 4 weeks after planting. Pre-emergence chemical weed control was done. An application of a combination of pendimethalin [N- (1- ethyl propyl) - 3, 4 - dimethyl -2, 6 - dinitrobenzenamine] and Gesaprim [2chloro -4 - (methylamino) -6- (isopropylamino) -5- triazine] at a rate of $1.51 \mathrm{ha}^{-1}$ and $1.01 \mathrm{ha}^{-1}$ were used at planting. Where there was heavy weed growth before planting, paraquat (1, 1- dimethyl -4, 4 - bipyridinium ion) was also applied at $1.01 \mathrm{ha}^{-1}$ in addition to pendimethalin and gesaprim. Hand weeding was also carried out to keep the experimental field free of weeds 4 weeks after planting. 
TABLe 1: Total rainfall and its distribution during the experimental period.

\begin{tabular}{lcccc}
\hline Rainfall $(\mathrm{ml})$ & & 2016 & & 2017 \\
& Total rainfall $(\mathrm{ml})$ & No. of rain days & Total rainfall (ml) & No. of rain days \\
\hline May & 45.6 & 5 & 38.4 & 4 \\
June & 166.0 & 8 & 68.9 & 5 \\
July & 122.9 & 10 & 146.4 & 12 \\
August & 240.0 & 15 & 180.5 & 15 \\
September & 195.6 & 20 & 227.5 & 16 \\
October & 153.1 & 11 & 124.3 & 7.6 \\
November & 0 & 0 & 0 & 0 \\
December & 0 & 0 & 793.6 & 61 \\
TOTAL & 923.2 & 69 & 99.2 & 7.6 \\
MEAN & 115.4 & 8.6 & & \\
\hline
\end{tabular}

Source: SARI Agrometeorological station reports, 2015.

TABle 2: Temperature distribution during the experimental period.

\begin{tabular}{|c|c|c|c|c|c|c|}
\hline \multirow{2}{*}{ Temperature $\left({ }^{\circ} \mathrm{C}\right)$} & \multicolumn{3}{|c|}{2016} & \multicolumn{3}{|c|}{2017} \\
\hline & Min. & Max. & Mean & Min. & Max. & Mean \\
\hline May & 26.8 & 35.5 & 31.2 & 25.9 & 35.5 & 30.7 \\
\hline June & 25.6 & 33.2 & 29.4 & 25.3 & 34.3 & 29.8 \\
\hline July & 24.9 & 30.9 & 27.9 & 24.2 & 30.7 & 27.5 \\
\hline August & 23.3 & 30.4 & 26.9 & 24.0 & 29.8 & 30.8 \\
\hline September & 23.1 & 30.5 & 26.8 & 24.0 & 27.5 & 27.4 \\
\hline October & 23.5 & 32.7 & 28.1 & 24.5 & 32.5 & 28.5 \\
\hline November & 24.3 & 35.6 & 30.0 & 23.2 & 35.7 & 29.5 \\
\hline December & 20.7 & 35.8 & 28.4 & 18.6 & 34.2 & 26.4 \\
\hline TOTAL & 192.2 & 264.6 & 228.7 & 189.7 & 260.2 & 230.6 \\
\hline MEAN & 24.0 & 33.0 & 28.5 & 23.7 & 32.5 & 28.8 \\
\hline
\end{tabular}

Source: SARI Agrometeorological station reports, 2015.

TABle 3: Relative humidity distribution during the experimental period.

\begin{tabular}{|c|c|c|c|c|c|c|c|c|c|}
\hline \multirow{2}{*}{ Relative humidity (RH \%) } & \multicolumn{3}{|c|}{2015} & \multicolumn{3}{|c|}{2016} & \multicolumn{3}{|c|}{2017} \\
\hline & Min. & Max. & Mean & Min. & Max. & Mean & Min. & Max. & Mean \\
\hline May & 60 & 83 & 73 & 56 & 83 & 70 & 67 & 85 & 76 \\
\hline June & 68 & 89 & 79 & 64 & 88 & 70 & 48 & 94 & 69 \\
\hline July & 75 & 93 & 84 & 71 & 91 & 81 & 56 & 94 & 75 \\
\hline August & 75 & 93 & 84 & 73 & 93 & 83 & 64 & 96 & 80 \\
\hline September & 74 & 89 & 79 & 75 & 93 & 84 & 72 & 94 & 83 \\
\hline October & 68 & 90 & 79 & 68 & 90 & 79 & 67 & 93 & 80 \\
\hline November & 53 & 82 & 68 & 54 & 82 & 68 & 39 & 74 & 57 \\
\hline December & 52 & 68 & 60 & 38 & 56 & 44 & 37 & 57 & 44 \\
\hline TOTAL & 525 & 687 & 606 & 499 & 676 & 579 & 450 & 687 & 564 \\
\hline MEAN & 65.6 & 85.8 & 75.7 & 62.3 & 84.5 & 72.3 & 56.2 & 85.8 & 70.5 \\
\hline
\end{tabular}

Source: SARI Agrometeorological station reports, 2015.

TABLE 4: Physicochemical characteristic of the soil at horizon $0-15 \mathrm{~cm}$ at Nyankpala

\begin{tabular}{lcc}
\hline Parameters & Value & Remarks \\
\hline Texture & Sandy loam & Mod. Acidic \\
$\mathrm{pH}$ & 6.50 & Low \\
Organic matter $(\mathrm{OC})$ & 1.9 & Very low \\
Total phosphorus $(\mathrm{P})\left(\mathrm{mgkg}^{-1}\right)$ & 1.80 & Very low \\
Organic carbon $\left(\mathrm{gkg}^{-1}\right)$ & 1.58 & Very low \\
Total nitrogen $(\mathrm{N})\left(\mathrm{gkg}^{-1}\right)$ & 0.65 & Low \\
Exchangeable potassium $(\mathrm{K})\left(\mathrm{cmol}^{\mathrm{k}} \mathrm{kg}^{-1}\right)$ & 0.65 & L \\
\hline
\end{tabular}

Source: Reproduced from Bawa, 2020; DOI: 10.9734/jeai/2020/v42i230475 
2.5. Data Collection and Analysis. During the 2016 and 2017 cropping seasons, the data on chlorophyll content, number of leaves, plant height, days to $50 \%$ tasselling, days to $50 \%$ silking, days to $50 \%$ physiological maturity, hundred seeds weight, total biomass production, number of grains per cob, and total grain yield were recorded and subjected to a combined analysis for variation in the factorial experiments in RCBD using Genstat statistical package edition 18. The means were separated using Duncan's multiple range test at a $5 \%$ probability level.

\section{Results}

\subsection{Effect of Variety on Growth Parameters}

3.1.1. Leaf, Shoot, and Biomass Production. The data for the two seasons were combined and analyzed, and the results indicated that the variety GH120 DYF/D POP produced the lowest number of 11 leaves, while OBATAMPA produced the highest number of 14 leaves (Table 5). There were significant differences $(p<0.05)$ between OBATAMPA and GH120 DYF/D POP with respect to leaf production (Table 6). COMP 1 SYN recorded the highest plant height of $181 \mathrm{~cm}$ whilst TZE-W-DT-STR-C4 recorded the least plant height of $121 \mathrm{~cm}$. There was a significant difference $(p<0.05)$ between COMP 1 SYN and TZE-W-DT-STR-C4 for shoot production. The total biomass production was the highest in OBATAMPA $(13,500 \mathrm{~kg} / \mathrm{ha})$. However, this was not significantly different $(p>0.05)$ from that of COMP 1 SYN, which recorded a biomass of $13,000 \mathrm{~kg} / \mathrm{ha}$.

3.1.2. Silk Production and Physiological Maturity. The variety COMP 1 SYN took a maximum of 68 days for silk production whilst DT-STR-W-C2 took a minimum of 59 days to produce silk (Table 5). There was a significant difference $(p<0.05)$ in terms of the number of days for silk production between the varieties COMP 1 SYN and DTSTR-W-C2 (Table 6). COMP 1 SYN took a maximum of 93 days to attain physiological maturity, and this was significantly different from all the other five varieties with respect to days to physiological maturity.

3.2. Effect of Variety on Grain Yield and 100-Grain Weight. OBATAMPA recorded the highest grain yield of 3.6 tons/ha under all $\mathrm{N}$ application rates (Table 5). The yield was, however, not significantly different $(p>0.05)$ from that of IWD-C3-SYN-F2 (3.5 tons/ha) (Table 6). The variety GH120 DYF/D POP produced the lowest grain yield of 2.5 tons/ha. For grain weight, OBATAMPA recorded the highest of $45 \mathrm{~g}$, however, this was not significantly different $(p>0.05)$ from that of IWD-C3-SYN-F2 (39g) and TZE-W-DT-STR-C4 $(39 \mathrm{~g})$.

\subsection{Effect of Nitrogen Rate on Growth Parameters}

3.3.1. Leaf, Shoot, And Biomass Production. All the varieties applied with $90 \mathrm{~kg} / \mathrm{ha} \mathrm{N}$ recorded an average of 13 leaves, whilst the varieties applied with $0 \mathrm{~kg} / \mathrm{ha} \mathrm{N}$ recorded the lowest of 10 leaves (Figure 1). There were no significant differences $(p>0.05)$ between the $90 \mathrm{~kg} / \mathrm{ha} \mathrm{N}$ application rate and the other application rates $(60$ and $120 \mathrm{~kg} / \mathrm{ha} \mathrm{N})$ with respect to leaf production (Table 6).

The control plants applied with $0 \mathrm{~kg} / \mathrm{ha} \mathrm{N}$ recorded the lowest biomass yield of $7500 \mathrm{~kg} / \mathrm{ha}$, whilst the varieties applied with $120 \mathrm{~kg} / \mathrm{ha} \mathrm{N}$ recorded the highest biomass yield $(15,000 \mathrm{~kg} / \mathrm{ha})$ (Figure 2). There were significant differences $(p<0.05)$ between the plants applied with $120 \mathrm{~kg} / \mathrm{ha} \mathrm{N}$ rate and 0 and $60 \mathrm{~kg} / \mathrm{ha} \mathrm{N}$ rate (Table 6) with respect to biomass production. However, the biomass production was significantly similar among the plants applied with 120 and $90 \mathrm{~kg} /$ ha $\mathrm{N}$.

3.3.2. Silk Production and Physiological Maturity. The control plants applied with $0 \mathrm{~kg} / \mathrm{ha} \mathrm{N}$ recorded the highest number of days (65 days) for $50 \%$ silking, whilst the varieties applied with $120 \mathrm{~kg} / \mathrm{ha} \mathrm{N}$ recorded the lowest of 58 days for silking (Figure 3 ). There were significant differences $(p<0.05)$ between the plants applied with $120 \mathrm{~kg} / \mathrm{ha} \mathrm{N}$ application rate and those applied with 0,60 , and $90 \mathrm{~kg} / \mathrm{ha} \mathrm{N}$ application rates with respect to the days to silk production (Table 6). The varieties applied with $90 \mathrm{~kg} / \mathrm{ha} \mathrm{N}$ took a maximum of 85 days to attain physiological maturity. However, this was not significantly different $(p>0.05)$ from the days taken to attain physiological maturity by the plants applied with $\mathrm{N}$ rates of 0 and $120 \mathrm{~kg} / \mathrm{ha}$ (Figure 4).

\subsection{Effect of Nitrogen Rate on Yield and Yield Components}

3.4.1. Grain Production per Cob. All the varieties applied with $120 \mathrm{~kg} / \mathrm{ha} \mathrm{N}$ recorded a maximum of 500 grains per cob, whilst the varieties applied with $0 \mathrm{~kg} / \mathrm{ha} \mathrm{N}$ recorded a minimum of 310 grains per cob (Figure 5). There were no significant differences $(p>0.05)$ between the $120 \mathrm{~kg} / \mathrm{ha} \mathrm{N}$ application rate and the other application rates of 60 and $90 \mathrm{~kg} / \mathrm{ha} \mathrm{N}$ with respect to grain production per cob (Table 6).

3.4.2. Grain Yield. The plants applied with $120 \mathrm{~kg} / \mathrm{ha} \mathrm{N}$ recorded the highest grain yield of 4 tons/ha, whilst the control plants applied with $0 \mathrm{~kg} / \mathrm{ha} \mathrm{N}$ recorded the lowest grain yield of 1.3 tons/ha (Figure 6). There were, however, no significant differences $(p>0.05)$ between the $120 \mathrm{~kg} / \mathrm{ha} \mathrm{N}$ and $90 \mathrm{~kg} / \mathrm{ha} \mathrm{N}$ application rates with respect to grain production (Table 6).

\section{Discussion}

From the study, the varieties applied with $90 \mathrm{~kg} / \mathrm{ha} \mathrm{N}$ were not significantly different from 0 to $120 \mathrm{~kg} / \mathrm{ha}$ with respect to the days taken to attain physiological maturity. It might occur as a result of the ineffective utilization of nitrogen by the plants that received $120 \mathrm{~kg} / \mathrm{ha} \mathrm{N}$. The erratic rainfall distribution and the amount of rainfall could have considerably influenced the response of maize to nitrogen application. It is because the rain might have caused the runoff and leaching of applied nitrogen. 
TABLE 5: Effect of variety on yield and growth parameters measured during the 2016 and 2017 cropping seasons.

\begin{tabular}{|c|c|c|c|c|c|c|c|}
\hline \multirow[b]{2}{*}{ Variety } & \multicolumn{7}{|c|}{ Growth and yield parameters } \\
\hline & $\begin{array}{l}\text { Number of } \\
\text { leaves }\end{array}$ & $\begin{array}{c}\text { Plant } \\
\text { height }(\mathrm{cm})\end{array}$ & $\begin{array}{l}\text { Days to } 50 \% \\
\text { silking }\end{array}$ & $\begin{array}{c}\text { Days to } 50 \% \\
\text { physiological maturity }\end{array}$ & $\begin{array}{l}\text { Total biomass (in } \\
1000 \mathrm{~kg} / \mathrm{ha} \text { ) }\end{array}$ & $\begin{array}{l}\text { 100-Grain } \\
\text { weight }(\mathrm{g})\end{array}$ & $\begin{array}{l}\text { Grain yield } \\
\text { (ton/ha) }\end{array}$ \\
\hline TZE-W-DT-STR-C4 & $13^{\mathrm{ab}}$ & $121^{\mathrm{d}}$ & $60^{\mathrm{cd}}$ & $83^{\mathrm{d}}$ & $11^{\mathrm{ab}}$ & $39^{\mathrm{ab}}$ & $2.8^{\mathrm{ab}}$ \\
\hline IWD-C3-SYN-F2 & $12^{\mathrm{abc}}$ & $131^{\mathrm{c}}$ & $65^{\mathrm{b}}$ & $90^{\mathrm{b}}$ & $13.5^{\mathrm{a}}$ & $39^{\mathrm{ab}}$ & $3.5^{\mathrm{a}}$ \\
\hline GH120 DYF/D POP & $11^{\mathrm{c}}$ & $161^{\mathrm{b}}$ & $60^{\mathrm{cd}}$ & $83^{\mathrm{d}}$ & $8^{\mathrm{b}}$ & $31^{\mathrm{c}}$ & $2.5^{\mathrm{b}}$ \\
\hline OBATAMPA & $14^{\mathrm{a}}$ & $158^{\mathrm{b}}$ & $66^{\mathrm{ab}}$ & $88^{\mathrm{c}}$ & $13.5^{\mathrm{a}}$ & $45^{\mathrm{a}}$ & $3.6^{\mathrm{a}}$ \\
\hline DT-STR-W-C2 & $12^{\mathrm{abc}}$ & $130^{\mathrm{c}}$ & $59^{\mathrm{d}}$ & $83^{\mathrm{d}}$ & $11^{\mathrm{ab}}$ & $36^{\mathrm{bc}}$ & $2.7^{\mathrm{ab}}$ \\
\hline COMP 1 SYN & $12^{\mathrm{abc}}$ & $181^{\mathrm{a}}$ & $68^{\mathrm{a}}$ & $93^{\mathrm{a}}$ & $13^{\mathrm{a}}$ & $38^{\mathrm{b}}$ & $2.9^{\mathrm{ab}}$ \\
\hline Mean & 12.1 & 147 & 62.9 & 86.1 & 11.7 & 38 & 2.9 \\
\hline SEM & 1 & 2 & 2 & 2 & 1 & 1 & 1 \\
\hline
\end{tabular}

SEM means standard error of the mean.

TABle 6: Analysis of variance for yield and yield components as influenced by varietal, N rates, and interaction effects in the 2016 and 2017 cropping seasons.

\begin{tabular}{|c|c|c|c|c|c|c|c|c|}
\hline \multirow[b]{2}{*}{$\begin{array}{l}\text { Source of } \\
\text { variation }\end{array}$} & \multirow[b]{2}{*}{$\mathrm{df}$} & \multicolumn{7}{|c|}{ F probability $(0.05)$} \\
\hline & & $\begin{array}{l}\text { Number of } \\
\text { leaves }\end{array}$ & $\begin{array}{l}\text { Plant height } \\
(\mathrm{cm})\end{array}$ & $\begin{array}{l}\text { Days to } 50 \% \\
\text { silking }\end{array}$ & $\begin{array}{c}\text { Days to } 50 \% \\
\text { physiological maturity }\end{array}$ & $\begin{array}{l}\text { Total biomass } \\
(\mathrm{kg} / \mathrm{ha})\end{array}$ & $\begin{array}{l}\text { 100-Grain } \\
\text { weight }(\mathrm{g})\end{array}$ & $\begin{array}{l}\text { Grain yield } \\
\text { (ton/ha) }\end{array}$ \\
\hline $\begin{array}{l}\text { Fertilizer rate } \\
(\mathrm{N})\end{array}$ & 3 & 0.000 & 0.000 & 0.000 & 0.000 & 0.000 & 0.000 & 0.000 \\
\hline Variety (V) & 5 & 0.042 & 0.000 & 0.000 & 0.000 & 0.002 & 0.000 & 0.009 \\
\hline $\mathrm{N} \mathrm{xV}$ & 23 & 0.253 & 0.240 & 0.348 & 0.224 & 0.360 & 0.439 & 0.472 \\
\hline Residual & 40 & & & & & & & \\
\hline Total & 71 & & & & & & & \\
\hline SE & & 1 & 2 & 2 & 2 & 1 & 1 & 1 \\
\hline CV (\%) & & 14.13 & 15.20 & 45.60 & 33.51 & 6.22 & 10.12 & 28.84 \\
\hline
\end{tabular}

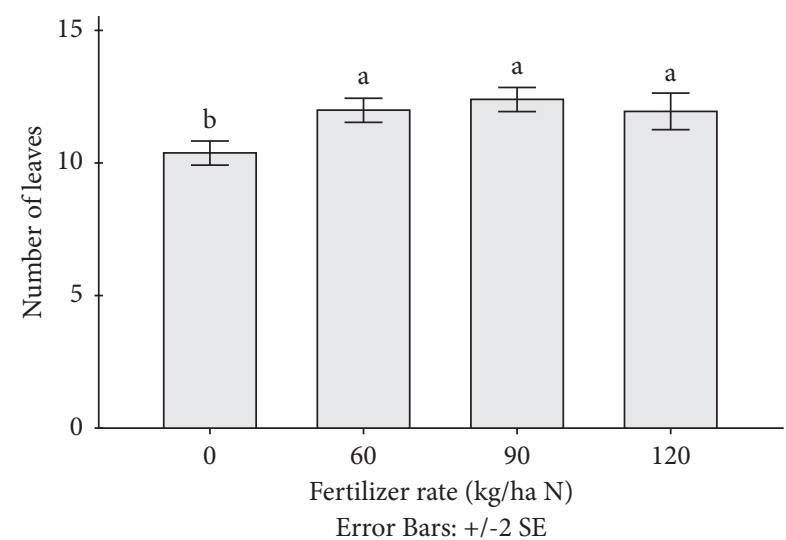

FIGURE 1: Effect of $\mathrm{N}$ rate on the number of leaves of maize grown under four fertilizer rates. Bars represent the standard error of mean.

Maize nitrogen use efficiency is estimated globally to be $33 \%$ because of the loss of $\mathrm{N}$ fertilizer from leaching below the root zone, denitrification, and soil- and plant-derived volatilization [20]. The inherent genetic factors could have also caused the uniformity of days to attain physiological maturity among the maize varieties. This observation confirms the findings of [21], who reported that maize varieties have a specific growth cycle. Chouhan et al. [22] also mentioned that genetic variability in growth and

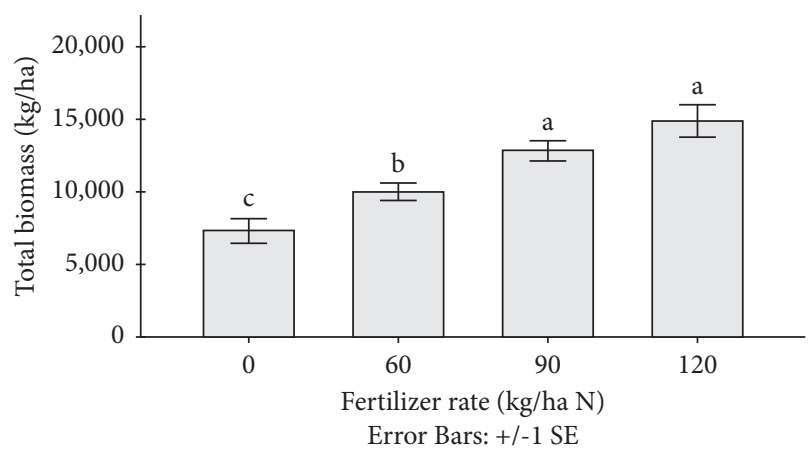

FIGURE 2: Effect of $\mathrm{N}$ rate on the biomass production of maize grown under four fertilizer rates. Bars represent the standard error of mean.

development exists among different maize cultivars, contributing to the differences in the observed days to $50 \%$ physiological maturity.

Silking and physiological maturity were earlier among DT-STR-W-C2, TZE-W-DT-STR-C4, and GH120 DYF/D POP but delayed among Comp 1 SYN and OBATAMPA for all nitrogen application rates. It is possible that DT-STR-WC2, TZE-W-DT-STR-C4, and GH120 DYF/D POP had a relatively high nitrogen use efficiency relative to the other varieties, resulting in an earlier production of silk. This result is supported by that of Khan et al. [23] but contravenes that 


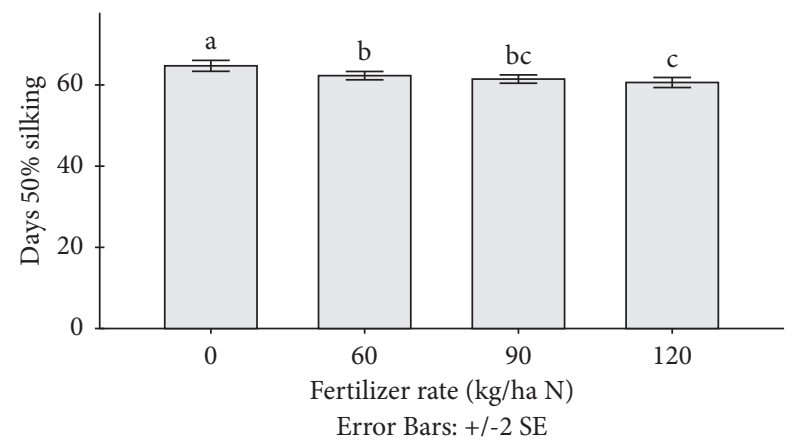

Figure 3: Effect of $\mathrm{N}$ rate on the days to $50 \%$ silking of maize grown under four fertilizer rates. Bars represent the standard error of mean.

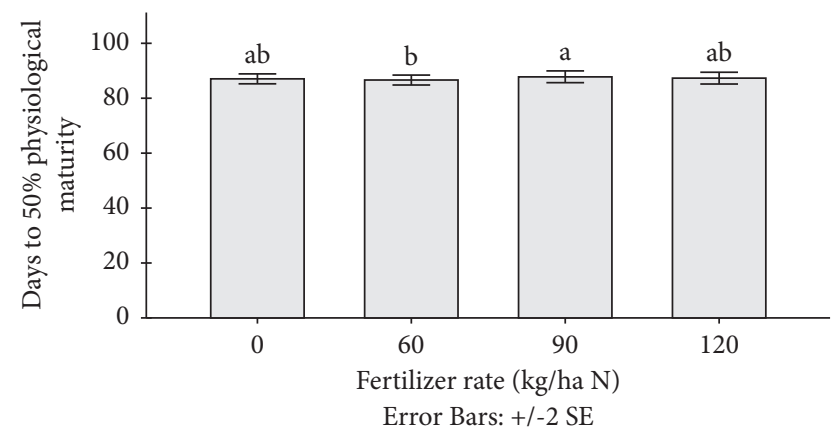

FIGURE 4: Effect of $\mathrm{N}$ rate on the days to $50 \%$ physiological maturity of maize grown under four fertilizer rates. Bars represent the standard error of mean.

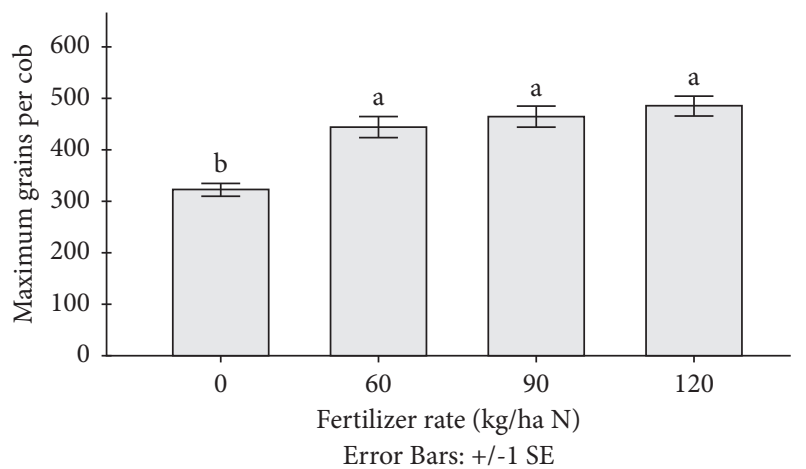

Figure 5: Effect of $\mathrm{N}$ rate on the maximum grain production per cob of maize varieties grown under four fertilizer rates. Bars represent the standard error of the mean.

of Hassan et al. [24], who revealed that maize cultivars had significant differences in the days to $50 \%$ silking and physiological maturity. The variation in maturity periods could be a result of genetic and environmental factors.

The studies of [25] and Bationo et al. [26] revealed that the growth, development, and maturity of maize are directly related to the number of nutrients that are made available to the plant during its growth period. Air-dried grain yield was the highest among OBATAMPA and IWD-C3-SYN-F2 but lowest among GH120 DYF/D POP. The observed increase in

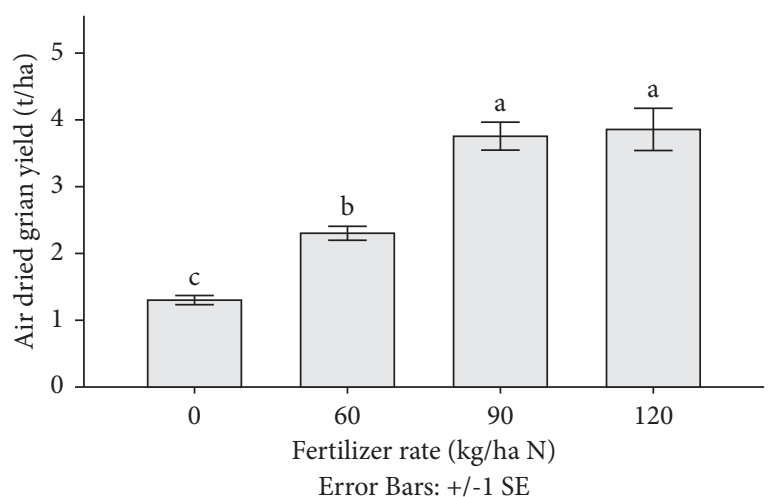

FIgURE 6: Effect of $\mathrm{N}$ rate on the grain yield of maize grown under four fertilizer rates. Bars represent the standard error of the mean.

yield with increasing $\mathrm{N}$ rates is in agreement with the finding of Singh et al. [27], who observed that a moderate absorption of nitrogen by the maize plants tends to increase its net returns. The differences in the yield of different varieties may be attributed to the existence of differences in the cultivars in terms of their reactions to external factors and utilization of soil and water resources, which also have a significant effect on the yield and other agromorphological parameters [28].

Reference [29] observed the genetic variability in the growth and development among different cultivars of maize. The highest number of leaves was recorded by OBATAMPA, however, it was not significantly different from that of TZEW-DT-STR-C4. It may be attributed to the inherent ability of these varieties to generate more leaves. However, GH120 DYF/D POP produced the least number of leaves. The variation in leaf production could have been because of the differences in response to different rates of $\mathrm{N}$ application. The variation in leaf appearance could also be a result of the crop's inherent ability to efficiently utilize soil resources.

Reference [30] also reported that increasing the nitrogen fertilizer rate from $0 \mathrm{~kg} \mathrm{~N} / \mathrm{ha}$ to $250 \mathrm{~kg} \mathrm{~N} / \mathrm{ha}$ significantly increased leaf production in the maize plants. IWD-C3SYN-F2 and OBATAMPA produced the highest biomass, however, it was not statistically different $(p>0.05)$ from that of COMP 1 SYN. The lowest biomass production was recorded by GH120 DYF/D POP. Reference [31] observed a significant disparity in the genotypes with respect to biomass production. The insignificant differences in the maximum grains per cob of the varieties are in contrast to the findings of Akmal et al. [31, 32], who observed significant differences in varieties with respect to the yield and other agromorphological traits. Generally, all treatments at $N>0 \mathrm{~kg} / \mathrm{ha}$ significantly produced more grains per cob than the control. The findings are partly in agreement with those of Maqsood et al. [33] and Sharar et al. [34], who observed that the number of grains per cob varied with different varieties.

In general, it was observed from the field data that the grain yield and yield components produced are related to the variation in $\mathrm{N}$ rates. All the varieties applied with $120 \mathrm{~kg} / \mathrm{ha}$ $\mathrm{N}$ recorded a relatively higher grain yield and several grains per cob as compared to the yields produced at 0,60 , and $90 \mathrm{~kg} / \mathrm{ha} \mathrm{N}$. [35] reported that increasing the $\mathrm{N}$ levels 
significantly increased the grain yield, days to $50 \%$ silk emergence, percent grain moisture content at harvest, and 1000 -seed weight, however, it negatively impacted the ear acceptability rating and percent total lodging. Nitrogen is a vital plant nutrient and a major yield-determining factor required for maize production [36].

Reference [37] reported that the nitrogen fertilizer levels are significant for grain yield, days to mid-silking, days to mid-anthesis, anthesis-silking interval, plant height, ear height, open tip, cob aspects, dry stover weight, cob length, and grain depth at nitrogen levels of 0,45 , and $90 \mathrm{~kg} \mathrm{~N} / \mathrm{ha}$. It may be because of adequate nitrogen in combination with $P$ and $K$, which greatly influenced the vegetative growth of the plant. The observed trend in cob weight confirms the results of [28], who observed significant differences in the cob weight among different genotypes at different $\mathrm{N}$ rates. Differences arise as a result of the difference in the genetic composition of the cultivars that also influence their responses to the external environment. On the contrary, Akmal et al. [32] observed no significant differences in cob weight for different varieties. Different $\mathrm{N}$ levels also produced significant differences in the empty cob weight. The results are supported by the findings of Hassan et al. [24], who reported that the grains per cob increased with the increasing levels of NPK fertilizers. The highest number of grains per cob was recorded at $120 \mathrm{~kg} / \mathrm{ha} \mathrm{N}$ across all the six genotypes used in the study.

\section{Conclusion and Recommendations}

The study was conducted to examine the varietal response of maize to different nitrogen fertilizer application rates. From the results and discussion of the experiment, the following conclusions were deduced:

The varieties OBATAMPA and IWD-C3-SYN-F2 produced the best results with respect to grain yield, total biomass, leaf, and shoot production. All the varieties applied with 120 and $90 \mathrm{~kg} / \mathrm{ha} \mathrm{N}$ recorded relatively higher grain yield and growth parameters as compared to 0 and $60 \mathrm{~kg} / \mathrm{ha}$ $\mathrm{N}$.

The cultivation of OBATAMPA and IWD-C3-SYN-F2 will result in an increased grain yield. The application of $90 \mathrm{~kg} / \mathrm{ha} \mathrm{N}$ will also result in increased grain production.

\section{Data Availability}

The data used to generate the results in this manuscript is not available.

\section{Additional Points}

This study discovered that the type of maize variety and nitrogen fertilizer rate used by the farmers for production influence the maize grain yield in the Savannah Agroecology of Ghana. The use of low-yielding varieties, coupled with an inappropriate nitrogen application rate is the major cause of the continuous low yield of maize in Northern Ghana. Through this study, the researcher had discovered that the use of varieties, such as OBATAMPA and IWD-C3-SYN-F2, and the application of $90 \mathrm{~kg} \mathrm{ha}^{-1} \mathrm{~N}$ will result in increased maize productivity in Northern Ghana.

\section{Conflicts of Interest}

The author has declared no conflicts of interest.

\section{Acknowledgments}

The author does acknowledge the critical comments and scientific inputs made by all researchers of the Department of Agronomy, University for Development Studies, Tamale; the CSIR-Savanna Agricultural Research Institute, Nyankpala, as well as the Millar Institute for Transdisciplinary and Development Studies, Bolgatanga. This research did not receive any specific funding.

\section{References}

[1] H. H. Ram, Crop Breeding and Biotechnology, p. 733, Kalyani Publishers, Ludhiana, India, 2011.

[2] J. Doebley, "Molecular evidence for gene flow among Zea species," BioScience, vol. 40, no. 6, pp. 443-448, 1990.

[3] DOA (Department of Agriculture), Maize Production, pp. 5-6, Department of Agriculture in Cooperation with ARC - Grain Crops Institute, Pretoria, 0001 South Africa, 2003.

[4] B. A. Bennett, "A mass mortality of fish associated with low salinity conditions in the Bot River estuary," Transactions of the Royal Society of South Africa, vol. 45, no. 3-4, pp. 437-447, 1985.

[5] I. Lawson, A. Issahaku, S. K. Acheampong, B. Adams, and V. Tuffour, "Time of planting and weed suppression abilities of some legumes intercropped with maize in the Guinea savanna zone of Ghana," Agriculture and Biology Journal of North America, vol. 4, no. 4, pp. 358-363, 2013.

[6] SARI (Savanna Agricultural Research Institute), Annual Report, pp. 1-16, Savanna Agricultural Research Institute (SARI). CSRI - SARI, Tamale, Ghana, 2020.

[7] IITA (International Institute of Tropical Agriculture), A Quarterly Bulletin of the Drought Tolerant Maize for Africa Projects, vol. 2, pp. 1-2, IITA (International Institute of Tropical Agriculture), Ibadan, Nigeria, 2013.

[8] E. Obeng-Bio, M. Bonsu, K. Obeng-Antwi, and R. Akromah, "Establishing the basis for drought tolerance in Maize (Zea Mays L.) using some secondary traits in the field," African Journal of Plant Science, vol. 5, no. 12, pp. 702-709, 2002.

[9] P. Abbott, "Stabilisation policies in developing countries after the 2007-08 food crisis," Agricultural Policies for Poverty Reduction, vol. 109, p. 2012, 2011.

[10] J. Rockström, J. Barron, and P. Fox, "Water productivity in rain-fed agriculture: challenges and opportunities for smallholder farmers in drought-prone tropical agroecosystems," Water Productivity in Agriculture: Limits and Opportunities for Improvement, no. 669, p. 85199, 2003.

[11] J. Rusike, N. M. Mahungu, S. Jumbo, V. S. Sandifolo, and G. Malindi, "Estimating impact of cassava research for development approach on productivity, uptake and food security in Malawi," Food Policy, vol. 35, no. 2, pp. 98-111, 2010.

[12] B. Biazin and G. Sterk, "Drought vulnerability drives land-use and land cover changes in the Rift Valley dry lands of Ethiopia," Agriculture, Ecosystems \& Environment, vol. 164, pp. 100-113, 2013. 
[13] N. Kurwakumire, R. Chikowo, F. Mtambanengwe et al., "Maize productivity and nutrient and water use efficiencies across soil fertility domains on smallholder farms in Zimbabwe," Field Crops Research, vol. 164, pp. 136-147, 2014.

[14] MoFA-SRID (Ministry of Food and Agriculture - Statistics, Resarch and Information Department), "Agriculture in Ghana: Facts and Figures, Ministry of Food and Agriculture - Statistics, Research and Information Directorate (MoFA - SRID), Accra, Ghana, 2011.

[15] I. K. Dzomeku, O. Illiasu, P. T. Birteeb, S. Obanyi, and T. Wood, "Modelling effects of residual organic materials on productivity of maize (Zea mays L.) for sustainable soil fertility restoration in the Guinea savannah zone," Current Agricultural Research, vol. 4, no. 2, 2016.

[16] C. E. Simpson and J. L. Starr, "Registration of 'COAN' peanut," Crop Science, vol. 41, no. 3, p. 918, 2001.

[17] S. Khan and E. Tamer, "Irregular identification, support conditions, and inverse weight estimation," Econometrica, vol. 78, no. 6, pp. 2021-2042, 2010.

[18] S. K. Bhanja, A. B. Mandal, S. K. Agarwal, and S. Majumdar, "Modulation of post-hatch growth and immuno-competence through in ovo injection of limiting amino acids in broiler chickens," Indian Journal of Animal Sciences, vol. 92, pp. 993-998, 2014.

[19] H. Brunner, "Radiation induced mutations for plant selection," Applied Radiation and Isotopes, vol. 46, no. 6-7, pp. 589-594, 1995.

[20] A. J. Sindelar, J. A. Coulter, J. A. Lamb, and J. A. Vetsch, "Nitrogen, stover, and tillage management affect nitrogen use efficiency in continuous corn," Agronomy Journal, vol. 107, no. 3, pp. 843-850, 2015.

[21] W. H. Verheye, "Food production or food aid? An African challenge," Finance and Development, vol. 37, no. 4, p. 38, 2000.

[22] D. Chouhan, S. R. Maloo, and D. Singh, "Studies on morphological and molecular diversity in specialty corn (Zea mays L.)," Indian Journal of Agricultural Research, vol. 5, no. 2, pp. 142-148, 2017.

[23] M. A. Khan, N. U. Khan, K. Ahmad, and M. Sadiq, "Yield of maize hybrid-3335 as affected by NP levels," Pakistan Journal Biology Science, vol. 2, no. 3, pp. 857-859, 1999.

[24] M. R. Hassan, J. T. Amodu, I. R. Muhammad et al., "Forage yield and quality of Lablab (Lablab purpureus L. Sweet) intercropped with maize (Zea mays L.) with flooded irrigation system in the semi-arid zone of Nigeria," Journal of Agricultural Science, vol. 6, no. 11, p. 196, 2014.

[25] N. K. Fageria and V. C. Baligar, "Enhancing nitrogen use efficiency in crop plants," Advances in Agronomy, vol. 88, pp. 97-185, 2005.

[26] A. Bationo, B. Waswa, A. Abdou et al., "Overview of long term experiments in Africa," in Lessons Learned from Long-Term Soil Fertility Management Experiments in Africa, pp. 1-26, Springer, Dordrecht, Netherlands, 2012.

[27] N. K. Singh, C. A. Bracker, P. M. Hasegawa et al., "Characterization of osmotin," Plant Physiology, vol. 85, no. 2, pp. 529-536, 1987.

[28] J. P. Azam, "Turning devaluation into pro-poor growth: Senegal 1994-2002," Determinants of Pro-poor Growth: Analytical Issues and Findings from Country Cases, 2007.

[29] H. A. Eagles and A. K. Hardacre, "Genetic variation in maize for early seedling growth in a low temperature environment," New Zealand Journal of Agricultural Research, vol. 22, no. 4, pp. 553-559, 1979.
[30] M. M. Badr and A. Authman, "Effect of plant density, organic manure, bio and mineral nitrogen fertilizers on maize growth and yield and soil fertility," Annals of Agricultural Science, Moshtohor, vol. 44, no. 1, pp. 75-88, 2006.

[31] F. B. Anjorin, "Comparative growth and grain yield response of five maize varieties to nitrogen fertilizer application," Greener Journal of Agricultural Sciences, vol. 3, no. 12, pp. 801-808, 2013.

[32] M. Akmal, H. U. Rehman, Farhatullah, M. Asim, and H. Akbar, "Response of maize varieties to nitrogen application for leaf area profile, crop growth, yield and yield components," Pakistan Journal of Botany, vol. 42, no. 3, pp. 19411947, 2010.

[33] M. Maqsood, A. M. Abid, A. Iqbal, and M. I. Hussain, "Effect of variable rate of nitrogen and phosphorus on growth and yield of maize (golden)," Journal of Biological Sciences, vol. 1, pp. 19-20, 2001.

[34] M. S. Sharar, M. Ayub, M. A. Nadeem, and N. Ahmad, "Effect of different rates of nitrogen and phosphorus on growth and grain yield of maize (Zea mays L.)," Asian Journal of Plant Sciences, vol. 2, no. 3, pp. 347-349, 2003.

[35] P. Kpotor, "Evaluation of newly released maize varieties in Ghana for yield and stability under three nitrogen application rates in two agro-ecological zones," Doctoral Dissertation, Kwame Nkrumah University of Science and Technology, Kumasi, Ghana, 2012.

[36] K. Shanti, V. P. Rao, M. R. Reddy, M. S. Reddy, and P. S. Sarma, "Response of maize (Zea mays) hybrid and composite to different levels of nitrogen," Indian Journal of Agricultural Sciences, vol. 67, no. 9, 1997.

[37] M. B. Ewool, "Estimation of genetic improvement of maize in Ghana under three levels of nitrogen application," Doctoral Dissertation, Kwame Nkrumah University of Science and Technology, Kumasi, Ghana, 2004. 